\title{
Edukacja przez sport i olimpizm w stronę dialogu, który nie dzieli lecz zbliża
}

Fundamentem życia społeczeństwa informacyjnego i społeczeństwa wiedzy jest komunikowanie. Obejmuje ono przekaz informacyjny i kulturowy, stanowi podstawę rozwoju cywilizacyjnego. W życiu publicznym komunikacja $\mathrm{w}$ formie wymiany informacji, dyskusji i argumentacji jest podstawą wszystkich społecznych, ekonomicznych i politycznych procesów decyzyjnych i jest w nim elementem niezbędnym. Hein Retter ${ }^{1}$ - podkreśla - że „Jedynie jednostka może uzyskać autonomię własnego Ja, dać wyraz własnej indywidualności, odpowiedzialnie postępować i regulować swoje stosunki z innymi ludźmi”. Bez komunikacji nie ma kształcenia i wychowania czyli edukacji. Dlatego ważne jest, aby osoby funkcjonujące zawodowo w edukacji posiadały kompetencje komunikacyjne. Dotyczy to głównie pedagogów, psychologów, a zwłaszcza nauczycieli-wychowawców, a także trenerów sportowych, terapeutów i innych. Z powyższych względów ważnym elementem edukacji stała się forma komunikacji określona mianem dialogu. Jest on najczęściej rozumiany jako sposób porozumiewania się człowieka z człowiekiem. Pojęcie dialogu jest wieloznaczne i wielowymiarowe, posiada wiele znaczeń. Dotyczy bowiem różnych sfer życia człowieka; poznawczej, społecznej, kulturowej. „Dialog - zdaniem

1 H. Retter, Komunikacja codzienna w pedagogice, tłum. M. Majdak-Piątkowska, wstęp i oprac. B. Śliwerski, GWP, Gdańsk 2005, s. 11. 
Genowefy Koć-Seniuch ${ }^{2}$ - jest najbardziej dojrzałą formą kontaktu międzyludzkiego. Kryjąc w sobie najgłębszy sens wychowania jest on podstawowym warunkiem ciągłości i zmiany w rozwoju osobowym człowieka". Rozmowa jest konstytutywną cechą dialogu, ale jest to taka rozmowa - precyzuje Jerzy Nikitorowicz ${ }^{3}$ - w której następuje: „wymiana myśli wartościujących określone zjawiska i problemy, połączone z pozytywnym kontaktem emocjonalnym i intelektualnym. Istotna jest symetryczność w procesie wymiany myśli, równość dawania i odbioru, wzajemności, podmiotowości obu stron prezentujących różne punkty widzenia".

Spośród licznych typów, rodzajów i określeń dialogu jako kontaktów międzyludzkich na potrzeby niniejszego wywodu najbliżej jest do dialogu pedagogicznego w ujęciu Janusza Tarnowskiego ${ }^{4}$. Wyróżnił on trzy zakresy występowania dialogu; jako metoda; jako proces; jako postawa. Metoda dialogu jest sposobem komunikacji przynajmniej dwóch podmiotów mającej na celu zbliżenie stanowisk, wzajemne zrozumienie prowadzące do współdziałania. „Proces dialogu zachodzi wtedy - podaje J. Tarnowski ${ }^{5}$ - gdy chociażby jeden z elementów zawartych w metodzie został uwzględniony". Postawa dialogu jest jakby efektem dwóch wcześniej wymienionych zakresów. Wyraża ona gotowość do zrozumienia, zbliżenia się i współdziałania z otoczeniem. Idąc tym tokiem myślenia dostrzegamy, iż dialog w edukacji kojarzy wizerunek ucznia z aktywnością, autonomią, krytycznym myśleniem i poszukiwaniem relacji w środowisku. Tym samym

wykracza poza zwyczajne przekazywanie wiadomości. O jego specyfice decyduje konstytutywna dla dialogu cecha - wymiana myśli. Uczestnicy dialogu pozostają partnerami refleksyjnej rozmowy, zaś ich wzajemny

2 G. Koć-Seniuch, Dialog, [w:] T. Pilch (red.), Encyklopedia pedagogiczna XXI wieku, t. 1, Wydawnictwo Akademickie Żak, Kraków 2003, s. 688.

3 J. Nikitorowicz, Heterogeniczność kultury $w$ indywidualnym dialogu tożsamościowym, [w:] A. Karpińska, M. Zińczuk, P. Remża (red.), Oblicza edukacji w prospektywnym oglądzie, Wydawnictwo Adam Marszałek, Toruń 2019, s. 45.

4 J. Tarnowski, Pedagogika dialogu, [w:] B. Śliwerski (red.), Edukacja alternatywna. Dylematy teorii i praktyki, Oficyna Wydawnicza „Impuls”, Kraków 1992; J. Tarnowski, Pedagogika egzystencjalna, [w:] Z. Kwieciński, B. Śliwerski (red.), Pedagogika, t. 1, PWN, Warszawa 2004.

5 Ibidem, s. 258. 
kontakt wymaga nie tylko opanowania mowy. Angażuje także uwagę, wyobraźnię, pamięć, procesy decyzyjne, myślenie ${ }^{6}$.

Istotą dialogu staje się więc pozyskiwanie przychylności, przyjaźni rozmówców, ludzi tworzących określone środowisko, społeczność. Dialog według Józefa Tischnera ${ }^{7}$ jest budowaniem przestrzeni wolności dla człowieka, stwarza warunki do myślenia. Jest to także spotkanie ludzi o duchowej bliskości. Na przykład w edukacji polega - zdaniem Mariana Śnieżyńskiego ${ }^{8}$ - „na zmniejszaniu się dystansu między duszą dziecka a duszą nauczyciela". Pisząc o dialogu edukacyjnym Genowefa Koć-Seniuch ${ }^{9}$ podkreśla, iż jest on: „(...) rozmową szczególną, pełną namysłu nad słowem i czynem. Jego istotą i celem są procesy uczenia się, a te są bardzo złożone i zależne od kultury komunikacyjnej nauczyciela". Odwołując się do kultury komunikacyjnej warto podkreślić istotę rozmowy, zwłaszcza w czasach nam współczesnych, kiedy to bardzo często spotykamy się, głównie w mediach z przykładami zaprzeczającymi istocie rozmowy. Chodzi przecież w niej nie tylko o mówienie, ale równie ważne jest słuchanie. Tymczasem utrwala się coraz mocniej, zwłaszcza w telewizji, obraz takich „rozmów”, w których każdy z kilku zaproszonych do studia rozmówców chce wypowiedzieć swoją kwestię nie wykazując zainteresowania sprawami innych, a nierzadko odchodzi od meritum sprawy, które miało być celem rozmowy. Zatem jest oczywiste, iż komunikacji należy się nauczyć, aby przygotować się do dialogu. Jednak droga do dialogu edukacyjnego - podkreśla Marian Śnieżyński ${ }^{10}$ - „nie jest ani prosta, ani łatwa, ale w imię dobra naszych uczniów, trud ten musi podjąć każdy nauczyciel i każdy rodzic. Bez zintegrowanych oddziaływań w tym względzie efektywność naszej pracy pozostawi wiele do życzenia”. Jednocześnie nie można ograniczać edukacji do jednostronnej transmisji wiadomości.

$6 \quad$ M. Śnieżyński, Dialog edukacyjny, Wydawnictwo Naukowe Papieskiej Akademii Teologicznej, Kraków 2001, s. 8.

7 J. Tischner, Polski kształt dialogu, Wydawnictwo Znak, Kraków 2002.

$8 \quad$ M. Śnieżyński, Dialog..., s. 12.

$9 \quad$ G. Koć-Seniuch, Dialog i humanizm w działaniu nauczyciela, [w:] J. Gajda (red.), O nowy humanizm w edukacji, Oficyna Wydawnicza „Impuls”, Kraków 2000, s. 405.

10 M. Śnieżyński, Dialog..., s. 408. 
Jest ona bowiem - zauważa Bogusław Milerski ${ }^{11}$ - dialogiem, w którym wszystkie uczestniczące strony (nauczyciele, uczniowie, rodzice) nie tylko przekazują informacje, lecz również ujawniają i urzeczywistniają wobec siebie wartości moralne, estetyczne i przynajmniej w niektórych przypadkach - religijne, nadające sens ich życiu.

Dialog edukacyjny może prowadzić i powinien prowadzić do świadomego i dobrowolnego podporządkowania się jednostki ludzkiej regułom życia społecznego. Szczególnie sprzyjające temu okoliczności powstają w toku działalności sportowej; treningu sportowego, współzawodnictwa, szkolenia sportowego. W sporcie bowiem funkcjonują silne, rzeczywiste autorytety; trenera, mistrza, olimpijczyka, rekordzisty, które zdecydowanie oddziałują na postawy, zwłaszcza ludzi młodych. W treningu i we współzawodnictwie sportowym jest sprzyjający klimat do wzmacniania współpartnerstwa. Wspiera ono kontaktowość, a ta symbolizuje dialog. Kontaktowość obejmuje stałe relacje trenera z zawodnikiem. Podczas tych relacji kształtują się postawy sportowca, które będą demonstrowane $\mathrm{z}$ udziałem lub bez udziału trenera. Bardzo często startując w zawodach, zwłaszcza najwyższego poziomu, zawodnik decyduje o sobie, o swoim starcie sam, bowiem trenera nie ma na stadionie. Do takich sytuacji, odpowiedzialnych decyzji, zawodnik musi być przygotowany. Dobrze jest jeśli owo przygotowanie odbywa się $\mathrm{w}$ dialogu podczas treningu sportowego. Trening jest procesem pedagogicznym, zatem sportowiec podczas treningu sportowego podlega podobnym rygorom dydaktyczno-wychowawczym, jak uczeń w szkole. Oczywiście przy uwzględnieniu specyfiki sportowej działalności, choćby faktu dobrowolności uczestnictwa. Tak więc wymogi stawiane nauczycielowi w procesie edukacji mogą być przenoszone do działań trenera. Proces ten powinien być tak prowadzony - podaje Anna Karpińska ${ }^{12}$ - „aby każdy uczeń miał poczucie własnej wartości, był aktywny jako osoba ucząca się, znał swoje mocne i słabe strony, gdyż to staje się źródłem motywacji wewnętrznej na rzecz własnego rozwoju. Zewnętrzny przymus i narzucanie dzieciom takiego samego

11 B. Milerski, Pedagogika religii, [w:] Z. Kwieciński, B. Śliwerski (red.), Pedagogika..., s. 277.

12 A. Karpińska, Responsywny nauczyciel wobec idei indywidualizacji procesu ksztatcenia, [w:] A. Karpińska, K. Borawska-Kalbarczyk, K. Kowalczuk (red.), Innowacje w edukacji w perspektywie jakości kształcenia, Wydawnictwo Adam Marszałek, Toruń 2019, s. 25. 
tempa pracy, zamiast je wspierać, negatywnie oddziałuje na ich rozwój, a czasem go blokuje". W treningu jest miejsce na wydawanie poleceń, nakazów i zakazów, ale z zachowaniem podmiotowości zawodnika. Dlatego podstawą treningu jest atmosfera współpartnerstwa. Partnerstwo w treningu sportowym obejmuje dostrzeganie i zrozumienie zawodnika i jego problemów przez trenera, a nade wszystko zawiera szacunek dla niego. Takie partnerstwo tworzy sytuacje sprzyjające samodzielnym wyborom, dokonywanym dla dobra zawodnika, a nie z nakazu trenera.

W treningu sportowym ukierunkowanym na dialog każdy z partnerów może mieć poczucie godności i wartości, dlatego też może się rewanżować poszanowaniem godności i wartości innych osób. Podstawą dialogu w sporcie jest współpraca i współdziałanie. Sport stwarza najlepsze możliwości, jakie trudno jest uzyskać w innych dziedzinach życia. Wyzwala wiarę w możliwości jednostki. Sprzyja kształtowaniu postaw twórczych i innowacyjnych. Klarownie wyznacza rolę do odegrania podczas treningu i współzawodnictwa. Dialog jest zjawiskiem pożytecznym i pożądanym, wszak pamiętać należy, iż nie jest tak łatwy i oczywisty. Jego istotę stanowi rozmowa, która może przecież skutkować różnymi efektami. Nie zawsze przecież i nie każda może wzmacniać relacje między ludźmi. Komunikatywność może prowadzić do różnych rezultatów. W naszych rozważaniach chcemy, aby ludzi łączyła, ale przecież nierzadko zdarza się, że dzieli. Dowodzi to potrzeby, wręcz konieczności przygotowania, wychowania człowieka do dialogu.

Celem tego opracowania jest ukazanie dialogu, który nie dzieli, lecz zbliża ludzi funkcjonujących w sporcie i wokół sportu. Ukazanie, że sport i jego ideologia - olimpizm tworzą w tym względzie szczególne możliwości. Dialog w procesie szkolenia sportowego umożliwia zdobywanie wiadomości i umiejętności, służy rozwojowi sportowca, wpływa na zrozumienie siebie, a także środowiska sportowego, a szerzej społecznego. Zadaniem trenera - jako organizatora wydarzeń sportowych - staje się więc konieczność organizowania relacji między uczestnikami treningu sportowego oraz środowiska sportu i wokół sportu. Wzajemne interakcje między trenerem a zawodnikiem powstające w toku treningu sportowego są przykładem dialogu edukacyjnego. O jakości i efektach pracy trenera decydują w znacznej mierze jego predyspozycje osobowościowe, a następnie twórcze poszukiwania merytoryczne i metodyczne, otwartość na kontakty z ludźmi, umiejętność 
słuchania innych, kierowanie się w pracy trenerskiej, w życiu sportowym, ale też pozasportowym, codziennym, zasadami moralno-społecznymi powszechnie uznawanymi.

Prezentowane opracowanie jest w pewnym zakresie normatywne, ale także odwołuje się do wyników badań empirycznych obejmujących istotę sportu, jego wartości. W badaniach wartości sportu odwołano się do doświadczeń badawczych opisanych przez Mirosława Józefa Szymańskiego ${ }^{13}$ w pracy Młodzież wobec wartości. Wykorzystując kwestionariusz ankiety, chcąc zmniejszyć nietrafność udzielanych odpowiedzi, zrezygnowano z pytań o bezpośredni stosunek badanych do określonych wartości na rzecz wskaźników uznawania bądź nieuznawania tych wartości. Badano również postawy dzieci, młodzieży, sportowców i kibiców wobec fair play w sporcie i w życiu społecznym, rozumienie przez dzieci i młodzież, sportowców, związków sportu z postawami moralnymi człowieka. Szczególną uwagę skierowano na olimpizm Pierre'a de Coubertina i jego przeobrażenia na przestrzeni ponad stu lat jako źródła wartości. Odniesiono się przede wszystkim do tych wartości, które sprzyjają tworzeniu dialogowej atmosfery. Dialog w edukacji sportowej traktujemy jako sztukę porozumiewania się, zdolność zaspokajania ciekawości nie tylko przez zdobywanie informacji, ale wiedzy i umiejętności, przez zrozumienie drugiego człowieka, innych osób.

\section{Wspólny świat wartości sportu i edukacji}

Wprowadzenie sportu i olimpizmu do systemu edukacji jest w wielu krajach, zwłaszcza europejskich, elementem strategii edukacyjnej XXI wieku. Sport ze swoimi uniwersalnymi wartościami ma służyć rozwojowi i wzbogacaniu zdrowia dzieci i młodzieży. W sporcie zawarta jest zasada czystej gry - fair play. Jest ona traktowana jako najważniejszy element etyki sportowej. Skupia w sobie cnoty powściągliwości, umiaru i ogłady cywilizacyjnej. Wzmacnia funkcję opiekuńczą współczesnej edukacji, która pokazuje potrzebę kształtowania odpowiedzialności moralnej ucznia za dokonywane wybory. Jednym z przejawów odpowiedzialności jest kierowanie się zasadą fair play przy ich dokonywaniu. Sport wyznacza dwa główne sposoby zachowania się człowieka.

13 M.J. Szymański, Młodzież wobec wartości. Próba diagnozy, IBE, Warszawa 1998. 
Pierwszy ma charakter rywalizacyjny, a więc stanowi konfrontację z innym człowiekiem, innymi ludźmi. Drugi to perfekcjonistyczny odnosi się do siebie samego. Obejmuje porównywanie osiąganych wyników rozwojowych, dążenie do przyjętych ideałów. Perfekcjonizacja w sporcie nie dotyczy wyłącznie fizyczności, ale jest całościowa, w tym również moralna, a zasada fair play nadaje specyficzny blask etyczny sytuacji podmiotowej. W edukacji przez sport chodzi nie tyle o rywalizację, a bardziej o współzawodnictwo, w którym uczestnik zabawy, gry nie jest rywalem, ale współpartnerem. We współzawodnictwie uczestnik sprawdza nie tylko to, czy jest lepszy od partnera, ale czy ma przekonanie, że sam jest dobry. Jest lepszy niż był wczoraj, ale nie tylko w wymiarze fizyczności, ale także w wymiarze moralnym. Sport sprawia, że wartości są dla człowieka wyznacznikiem kierunku własnej działalności, a także sposobu interpretowania działalności innych osób. Wartości tkwiące w zasadzie fair play - zdaniem Zofii Żukowskiej ${ }^{14}$ „wyznaczają i integrują postawy wobec innych osób, a także określają sieć poznawczą osoby". Mogą spełniać funkcję motywacyjną do właściwych wyborów w sporcie, a także stanowić cel edukacyjny. Sport tworzy w edukacji szansę na rzeczywiste nauczanie przez przeżywanie. Z badań empirycznych m.in. Józefa Lipca ${ }^{15}$, Tadeusza Maszczaka ${ }^{16}$, Jerzego Nowocienia $^{17}$, Andrzeja Michała de Tchorzewskiego ${ }^{18}$, KrzysztofaZuchory $^{19}$,

14 Z. Żukowska, Dzieci o sporcie a jego wartości edukacyjne, [w:] E.A. Wesołowska (red.), Człowiek i edukacja. Studia ofiarowane Profesorowi Józefowi Półturzyckiemu z okazji 70-lecia urodzin i 50-lecia pracy naukowej, Wydawnictwo Naukowe Novum, Płock 2004, s. 276.

15 J. Lipiec, Sport przyjemne z pożytecznym. Dla zdrowia, zabawy, wypetniania pustki, [w:] J. Nowocień, K. Zuchora (red.), Sport w kulturze zdrowia, czasu wolnego i edukacji olimpijskiej, Akademia Wychowania Fizycznego, PAOl, Fundacja „Centrum Edukacji Olimpijskiej”, Warszawa 2013; J. Lipiec, Homo olimpicus, Fall, Kraków 2017.

16 T. Maszczak, Wychowanie przez rozwój, Fundacja „Centrum Edukacji Olimpijskiej”, Warszawa 2014.

17 J. Nowocień, Sport i olimpizm w systemie dydaktyczno-wychowawczym współczesnej szkoły, AWF, Warszawa 2001; Idem, Studium o pedagogice kultury fizycznej, Akademia Wychowania Fizycznego, Warszawa 2013; Idem, Pedagogika sportu, Akademia Wychowania Fizycznego, Warszawa 2019.

18 A.M. de Tchorzewski, Sprawności moralne - nauczyciela wychowania fizycznego, „Wychowanie Fizyczne i Zdrowotne” 2010, nr 2, s. 21.

19 K. Zuchora, Nauczyciel i wartości z filozofii kultury fizycznej i pedagogiki sportu, Akademia Wychowania Fizycznego, Warszawa 2009; Idem, Dialogi olimpijskie. O pięknie i pokoju. Etyce i polityce. Solidarności i edukacji, Fundacja „Centrum Edukacji Olimpijskiej", Warszawa 2016. 
Zofii Żukowskiejej ${ }^{20}$ i Ryszarda Żukowskiego ${ }^{21}$, w tym także przeprowadzonych metodą eksperymentu wynikają jednoznacznie wartości sportu, które uczniowie znają, akceptują, które motywują ich do uczestnictwa w sporcie.

Nadrzędnymi wartościami w sporcie są wartości edukacyjne. Wynikają z poznawczego i wychowawczego aspektu sportu. Jest on źródłem wiedzy, zwłaszcza o możliwościach człowieka jako jednostki, ale także jako uczestnika życia społecznego. Wartości edukacyjne obejmują sferę intelektualną (poznawczą) i wolicjonalno-emocjonalną (wychowawczą). Podkreślają istotę sportu i jego specyficzny charakter; pedagogiczny, kulturowy i społeczny.

Wartości poznawcze wynikają z możliwości poznawania rzeczywistości przez sport, przez uczestnictwo w nim. Ułatwiają zdobywanie wiedzy o samym sobie i o innych ludziach. Sportowcy poznają „wiarygodność sprawdzianów ludzkich dokonań i wyznaczania potencjału fizycznego i psychofizycznego w poszczególnych konkurencjach, poznają związki przyczynowo skutkowe między sferą wrodzoności a pracą treningową"22. Poznają sport w wielorakich przejawach i uwarunkowaniach, w tym także negatywnych. Zapoznają się z mechanizmami przekształcania rzeczywistości, zmieniania świata za pomocą sportu. Wartości poznawcze analizowane są w kategoriach wiedzy zawodnika, jego sprawności myślenia i działania. Faktor aktywności intelektualnej stanowi istotny warunek efektywności treningu sportowego i współzawodnictwa. Uczestnictwo w sporcie mobilizuje do nauki i innych czynności szkolnych lub akademickich.

Wartości wychowawcze przejawiają się zdolnościami kształtowania własnej osobowości. Wyrażają się pracą nad doskonaleniem siebie przez aktywność sportową. Realizują się przez osobotwórcze właściwości sportu. Faktyczne wartości wychowawcze sportu są silnie uargumentowane wynikami badań pedagogicznych, w tym prowadzonych

20 Z. Żukowska, Fair play w europejskiej kulturze i edukacji, [w:] Z. Żukowska, R. Żukowski (red.), Fair play w europejskiej kulturze i edukacji, Polski Komitet Olimpijski, Klub Fair Play, Warszawa 2004.

21 Z. Żukowska, R. Żukowski (red.), Wychowanie poprzez sport, Ministerstwo Edukacji Narodowej i Sportu, Polskie Towarzystwo Naukowe Kultury Fizycznej, Warszawa 2003; Z. Żukowska, R. Żukowski (red.), Fair play w europejskiej kulturze i edukacji, Polski Komitet Olimpijski, Klub Fair Play, Warszawa 2004.

22

J. Lipiec, Homo..., s. 185. 
metodą eksperymentu. Sport wyzwala pozytywne interakcje społeczne, w wyniku których kształtują się postawy odpowiedzialności, samostanowienia oraz umacniania się poczucia własnej wartości. Pod wpływem sportu zmieniają się w kierunku pozytywnym postawy sportowców. Ich zachowanie posiada dodatni wpływ na integrację społeczną, np. klas szkolnych, szkół, drużyn sportowych, klubów, środowiska lokalnego i innych. Sport może i oddziałuje na zachowania zbiorowości, może pobudzić i ożywić relacje interpersonalne, pobudzić do dialogu. Tym samym może niezwykle wzbogacić społeczeństwo.

Wartości witalno-zdrowotne stanowią ważny aspekt sportu. Zdrowie człowieka jest warunkiem uczestnictwa w sporcie. Zwłaszcza tym wyczynowym. Dlatego wymaga troski i wspierania. Sport prowadzi do zachowania i podniesienia poziomu zdrowia. Człowiek zdrowy może sprawnie wykonywać, trudne i złożone ćwiczenia sportowe. Zaburzenia zdrowia, choroba, stanowią trudności i przeciwwskazania dla aktywności sportowej. Z jednej strony sport służy podniesieniu sprawności, ale z drugiej, konieczne jest zdrowie do wykonania zadań sportowych. „Sport okazuje się społecznie uznaną formą prezentacji zdrowia poprzez ujawnienie i realizację sprawności człowieka, przechodząc ze stanu potencjalności (tego, co człowiek mógłby uczynić) do stanu $a k-$ tualizacji osobniczej energii tego, co faktycznie czyni"23. Sport spełnia wobec zdrowia funkcje rehabilitacyjne i od twórcze, przywraca zdrowie osobom podupadłym na zdrowiu. Podtrzymuje, rozwija i optymalizuje sprawność fizyczną. Wartości zdrowotne sportu warunkują osiąganie sukcesów sportowych, a z drugiej strony rozważna i racjonalna praktyka podnosi znaczenie sportu jako ważnej dziedziny życia społecznego.

Wartości hedonistyczne to przyjemności z oglądania widowiska, imprezy sportowej. Widz czerpie satysfakcję z oglądania efektów pracy sportowców, którzy podobnie jak aktorzy w teatrze są mistrzami swojego fachu na stadionach, w halach, boiskach. Hedonizm widowiska sportowego wyraża się dramaturgią gry, nieprzewidywalnością jej przebiegu, a zwłaszcza końcowego rezultatu. Widowisko sportowe jest areną „określania zuniwersalizowanej pozycji naszej reprezentacji, naszych zawodników i pośrednio nas samych"24. To w takich warunkach następuje identyfikacja z własną drużyną, narodem, państwem,

23 J. Lipiec, Sport przyjemne..., s. 29.

24 Ibidem, s. 31. 
klubem lub regionem. Wzmacniają się wówczas więzi społeczne. Sport jest źródłem przyjemności i radości. Dlatego ma powszechne uznanie dzieci, młodzieży i dorosłych w każdym wieku. Przez sport poznają oni podstawowy mechanizm społeczny, jakim jest współdziałanie.

„Współpraca sportowa - pisał Pierre de Coubertin ${ }^{25}$ - posiada cechy szkoły przygotowawczej do demokracji. W rzeczywistości państwo demokratyczne nie może żyć i prosperować bez tego połączenia, wzajemnej pomocy i współzawodnictwa, jakie jest fundamentem społeczności sportowej i pierwszym warunkiem jej powodzenia". Sport od najmłodszych lat uczy zasad współdziałania. Wzbogaca współpracę, tworzy warunki do szybkiego uczenia się życia, poznawania norm. Przechodzi stopniowo od elementów najłatwiejszych do złożonych, jak w grach zespołowych. Współdziałanie sportowe jest więc nośnikiem wartości zespołowych-społecznych-hedonistycznych, zwykle eliminuje egoizm. Dlatego to sport postrzegany bywa jako instytucja wychowawcza mogąca w sposób bezpośredni i atrakcyjny przygotować człowieka do życia w demokracji.

Wartości estetyczne kojarzone są z pięknem, wzniosłością, wywołują poczucie przyjemności intelektualnej, emocjonalnej. Tworzą sferę cennych doznań, przeżyć. Wartości estetyczne sportu są źródłem i inspiracją dla ludzi kultury, sztuki, poezji i literatury. Są również wokół sportu, wszędzie tam, gdzie istnieje twórczość dla sportu i o sporcie.

Współczesny sport nadal czerpie z kultury starożytnej Grecji, tworzy nowy obraz odpowiedni do warunków cywilizacyjnych. Dostrzegamy w nim dzieło natury czyli piękno ciała ludzkiego, a także dzieło pracy człowieka czyli dynamikę ruchu, perfekcjonizm etyczny. Tak więc piękno sportu znajduje się na styku natury i sztuki. Potocznie używa się nazwy rzeźbienie jako modelowanie ciała i przygotowanie go do wymagań mody lub dyscypliny sportowej. Wartości estetyczne sportu tkwią w działaniach sportowca, w pięknie ruchu jako wysiłku wielogodzinnych, trudnych i uciążliwych treningów.

Wartości etyczno-perfekcjonistyczne stanowią o istocie sportu i są jego najważniejszymi walorami. Choć uczestnictwo w sporcie związane jest bezpośrednio ze sferą somatyczno-biologiczną człowieka, to

25 P. Coubertin, Przemówienia. Pisma różne i listy, przedruk i oprac. G. Młodzikowski przy współpracy K. Hądzelka, Polskie Towarzystwo Naukowe Kultury Fizycznej, Warszawa 1994, s. 126. 
jednak nie tylko ciało uczestniczy w grze sportowej, ale cały człowiek. Sport bowiem angażuje sferę intelektualną, emocjonalną, wolność wyboru, odpowiedzialność i godność. Uczestnicząc w sporcie człowiek manifestuje nie tylko walory sprawności fizycznej, ale także charakteru i silnej woli. Wartości etyczno-perfekcjonistyczne wiążą problematykę moralną z perfekcyjnym dążeniem do mistrzostwa sportowego. Sport kształtuje człowieka fizycznie, a także moralnie. Z jednej strony wymaga posiadania sprawności moralnej, z drugiej powoduje ich rozwój i utrwalanie. W istocie sportu zawarta jest skłonność do walki, rywalizacji, współzawodnictwa. Skłonności te mieszczą się w naturze człowieka. Mogą one być wykorzystane pozytywnie, ale także negatywnie. Dlatego rolą trenera, wychowawcy, ludzi organizujących sport jest takie ukierunkowanie zachowań sportowca, aby energia i wola walki przebiegały w granicach uznanych za cywilizacyjne i moralne, akceptowane społecznie. Wszystkie te wartości współgrają z celami i zadaniami reformowanej polskiej szkoły ${ }^{26}$.

Wartości sportu odgrywają istotną rolę w życiu sportowca i funkcjonowaniu sportowej wspólnoty. Wszystkie mają podobną wagę i wynikają z potrzeb. Dlatego nie należy ich hierarchizować. Warto natomiast je poznawać, przyswajać i czynić z nich użytek wychowawczy. Dzieje się to m.in. w procesie dążenia do perfekcji realizowanych zadań sportowych. Sportowiec osiąga perfekcję z zachowaniem moralnych uwarunkowań. Wyniku nie przecenia wyłącznie dla niego samego ${ }^{27}$.

\section{Olimpizm źródłem poznania świata i samego siebie}

Wprowadzone przez Coubertina pojęcie olimpizmu obejmuje doktrynalny i instytucjonalny system stanowiony przez igrzyska olimpijskie oraz kierowany przez Międzynarodowy Komitet Olimpijski ruch olimpijski. Podstawą ruchu olimpijskiego jest humanistyczna filozofia wychowania w skali całego świata. W tym ujęciu olimpizm stanowi nadbudowę igrzysk olimpijskich. W przekonaniach Coubertina miał on funkcjonować jako uniwersalny, demokratyczny i międzynarodowy

26 Rozporządzenie Ministra Edukacji Narodowej z dnia 27 sierpnia 2012 r. w sprawie podstawy programowej wychowania przedszkolnego oraz kształcenia ogólnego w poszczególnych typach szkół (Dz.U. 2012, poz. 977).

27

J. Nowocień, Pedagogika sportu..., s. 235-236. 
system służący do wychowania ludzi przez sport, który jako rodzaj gry, także zespołowej posiada określone przepisy i zasady. Ich znajomość i przestrzeganie jest obowiązkiem każdego sportowca, każdego uczestnika gry. Zasady w sporcie są jego siłą moralną. Są przyjęte dobrowolnie, są klarowne, mają powszechną aprobatę. Obowiązują wszystkich uczestników $\mathrm{w}$ równym stopniu. Tak więc realizuje się podstawowa zasada moralna równości ludzi wobec siebie. Boisko sportowe może sprzyjać wychowaniu, okazywaniu szacunku i tolerancji, zbliżać ludzi i umacniać solidarność między nimi. Wrażliwość moralną, chęć pomocy innym, zwłaszcza słabszym i potrzebującym odnajdujemy w zasadzie fair play. To ona w zdecydowanej mierze nadaje sens i podnosi atrakcyjność współzawodnictwa sportowego. Jest źródłem wartości moralnych w sporcie, a jednocześnie zdaje się spełniać znamiona dialogu edukacyjnego. Skłania nie tylko do przestrzegania obowiązujących przepisów i reguł sportowych, ale ma także - podkreśla Andrzej Michał de Tchorzewski -

uczyć wzajemnego szacunku, ma uczyć odpowiedzialności, uczciwości, sprawiedliwości, wytrwałości, odwagi, znoszenia trudu i niewygód, solidarności, wierności obowiązkom i pewnie wielu jeszcze innych właściwości osobistych, które decydują o postawie sportowca oraz o jakości jego stosunku i relacji z innymi uczestnikami gier, zabaw i zmagających się we współzawodnictwie sportowym ${ }^{28}$.

Olimpizm miał być w zamierzeniach Coubertina wykorzystywany instrumentalnie jako praktyczna szkoła moralnego, intelektualnego i fizycznego doskonalenia jednostki ludzkiej, a w konsekwencji kosmopolitycznego społeczeństwa, przy poszanowaniu poszczególnych narodów, uznawaniu ich kulturowych odrębności. Działalność Coubertina dotyczy lat siedemdziesiątych XIX wieku, kiedy to załamał się mit o potędze Francji. Dlatego zastanawiał się on nad sposobem odbudowania społeczeństwa francuskiego. Szansę widział w odpowiednio zorganizowanej i prowadzonej edukacji. Dążył do odrodzenia antycznego kultu ciała, do odnowy biologicznej społeczeństwa. Wizję szkoły stworzył na podstawie raportu, który ukazał nędzę ówczesnej szkoły francuskiej. Napiętnował jednostronność intelektualną, edukacyjną powierzchowność, encyklopedyzm. Chciał wnieść do szkoły

28 A.M. de Tchorzewski, Sprawności moralne..., s. 21. 
nowe treści, ukazał urodę życia i radość z faktu twórczego stawania się człowiekiem poszukującym oparcia w sobie, odkrywającym najpierw siebie, a następnie innych. Wszystko to miało odbywać się przez wprowadzenie do szkoły sportu. Stworzył podstawy nowej pedagogiki wykorzystującej walory sportu. Coubertin wierzył, że odrodzony ruch olimpijski przyczyni się do moralnego rozwoju ludzkości i pokoju społecznego, stanie się uniwersalną doktryną obejmującą swym wpływem ludzi różnych ras, religii, ideologii i kultur. U kresu swego życia patrzył z satysfakcją na przebytą drogę tego ruchu, a ta przebiegała przez wszystkie kontynenty. Z dumą podkreślał fakt ciągłego ruchu i to, że kolejne pokolenia młodzieży manifestują swe przywiązanie do olimpijskich ideałów: prawdy, piękna, pokoju i braterstwa.

Podstawą pedagogiki sportowej - olimpijskiej uczynił Coubertin główne wartości: zabawę, piękno, sprawiedliwość. Domagał się, aby szkoła przygotowywała do życia, a nade wszystko, aby służyła rozwojowi dziecka. Wychowanie powinno odbywać się przez rozwój, a rozwój powinien odbywać się przez radość. Podstawę edukacji sportowej stanowi antyczna myśl filozoficzna „poznaj samego siebie”. „Stworzona w kręgu boiska, objęła z czasem cały horyzont ludzkiego życia. Dziś stanowi podstawę szkolnej filozofii" ${ }^{29}$. Sport jest niezwykłą drogą samopoznania, poszukującą uzasadnienia, aby siły ducha mogły przezwyciężyć ograniczone przez naturę możliwości ciała. Bowiem „Siła sportowca nie leży wyłącznie w jego mięśniach, a przeszkodą na drodze do sukcesu nie jest jedynie słabość ciała. Zalety duchowe, które nie zawsze są widoczne dla oka, zajmują pierwszoplanowe miejsce"30. Tak więc sukces sportowy jest wynikiem silnej woli wspomożonej rozwagą. Dlatego to rozwój fizyczny i trening sportowy stanowią dla młodzieży najlepszą ochronę moralną, a jednocześnie korzystnie podkreślają jej osobowość. Edukacja sportowa ukazuje - dowodzi Krzysztof Zucho$\mathrm{ra}^{31}$ - niezwykłą rolę boiska w pełnym rozwoju osobowym człowieka". Na boisku szkolnym w zabawie i współzawodnictwie sportowym odbywa się porównanie sił natury, a jakość stosunku do drugiego człowieka określa jednoznacznie sukces albo porażkę. Mamy tu do czynienia z poznawaniem człowieka, a także samego siebie. Jest więc typowy

29 K. Zuchora, Nauczyciel..., s. 347.

30 Ibidem, s. 294.

31 Ibidem, s. 342. 
przykład, jak pisał Karol Wojtyła ${ }^{32}$ „człowiek w pełni odkrywa samego siebie wyłącznie w relacji do drugiego człowieka". Sport ma trwałe miejsce w edukacji i kulturze, ponieważ wspiera biologiczną naturę człowieka, sprzyja rozwojowi intelektualnemu i moralnemu, wskazuje prymat ducha nad ciałem. W sporcie mamy sytuacje, w których dobry przykład jest w stanie zastąpić mnóstwo słów. Dlatego to wszelkie nauki, których udzielają sobie chłopcy i dziewczynki na boisku szkolnym, są dla nich nierzadko bardziej pożyteczne, niż wiele słów wypowiedzianych przez nauczyciela w klasie. Sport określa własne prawa i zasady, a jednocześnie uczy poszanowania praw i zasad ogólnych. Przyjaźń zrodzoną we własnym kręgu przenosi poza ten krąg, do życia poza sportem, w społeczności lokalnej, po globalną włącznie. Przez sport jednostka uczy się włączenia własnych wartości do wspólnych zasad. To na boisku jednostki włączają swoje indywidualne cele i wyczyny w jeden wspólny drużynowy - zespołowy. Boisko staje się konkretnym przykładem rozwiązywania konfliktów w sposób pokojowy, pokazuje, jak nierówność można podporządkować demokracji: a nawet walkę poprowadzić w stronę dialogu, który nie dzieli, lecz zbliża.

\section{Konstatacje}

Sport jest nieodłączną składową wychowania, czynnikiem kultury humanistycznej. Przez właściwości perfekcjonistyczne posiada najwyższy walor wychowawczy. Skłania do wysiłku samowychowania: dochodzenia do doskonałości w podjętym wysiłku, przezwyciężania samego siebie, własnych słabości. Stanowi drogę spotkania - dialogu z drugim człowiekiem. W sporcie człowiek realizuje swoje prawa do zabawy, godności i wolności, samostanowienia o sobie. Na podstawie własnych dokonań jednostka tworzy obraz samego siebie, a ponieważ funkcjonuje w środowisku społecznym buduje ten obraz licząc się z ocenami innych. W wychowaniu przez sport chętnie wykorzystujemy przykład boiska, bowiem to ono wskazuje jednostce drogę do spotkania z innymi. To spotkanie jest sporem, walką, wysiłkiem i napięciem emocjonalnym, w którym zwycięstwo, choć staje się najważniejszą sprawą, to jednocześnie jest wyborem w kwestiach zasadniczych,

32 K. Wojtyła, Osoba i czyn oraz inne studia antropologiczne, Towarzystwo Naukowe KUL, Lublin 2000, s. 22. 
takich jak dobro i zło. Wybór odbywa się w zgodzie z samym sobą i relacjach z innymi, którzy współtworzą obraz świata. Edukacja przez sport jako środek wychowania i olimpizmu jako źródło wartości jest korzystna dla autoedukacji: tworzy możliwości poszukiwania własnej tożsamości oraz drogi do przekraczania samego siebie. Relacje w sporcie wyznaczają przestrzeń wartości, najpierw duchowych a następnie cielesnych. Określają kierunek działania w stronę drugiego człowieka odwołując się do pedagogiki spotkania - pedagogiki dialogu.

\begin{abstract}
The aim of my research was to present the role of dialogue in sports education. The dialogue is a device in communication enabling not only getting information and knowledge but also insight into other people. Through sports a person is learning to incorporate values into common rules. Sport, play, and the playing field show how to subordinate inequality to democracy and change fighting into a dialogue bringing people together. This kind of dialogue in sports education is only possible thanks to the values of sports and Olympism which is a source of universal values.
\end{abstract}

\title{
Bibliografia
}

Coubertin P., Przemówienia. Pisma różne i listy, przedruk i oprac. G. Młodzikowski przy współpracy K. Hądzelka, Polskie Towarzystwo Naukowe Kultury Fizycznej, Warszawa 1994.

Karpińska A., Responsywny nauczyciel wobec idei indywidualizacji procesu kształcenia, [w:] A. Karpińska, K. Borawska-Kalbarczyk, K. Kowalczuk (red.), Innowacje w edukacji w perspektywie jakości kształcenia, Wydawnictwo Adam Marszałek, Toruń 2019.

Koć-Seniuch G., Dialog i humanizm w działaniu nauczyciela, [w:] J. Gajda (red.), O nowy humanizm w edukacji, Oficyna Wydawnicza „Impuls", Kraków 2000.

Koć-Seniuch G., Dialog, [w:] T. Pilch (red.), Encyklopedia pedagogiczna XXI wieku, t. 1, Wydawnictwo Akademickie Żak, Kraków 2003.

Lipiec J., Sport przyjemne z pożytecznym. Dla zdrowia, zabawy, wypetniania pustki, [w:] J. Nowocień, K. Zuchora (red.), Sport w kulturze zdrowia, czasu wolnego i edukacji olimpijskiej, Akademia Wychowania Fizycznego, PAOl, Fundacja „Centrum Edukacji Olimpijskiej”, Warszawa 2013.

Lipiec J., Homo olimpicus, Fall, Kraków 2017. 
Maszczak T., Wychowanie przez rozwój, Fundacja „Centrum Edukacji Olimpijskiej”, Warszawa 2014.

Milerski B., Pedagogika religii, [w:] Z. Kwieciński, B. Śliwerski (red.), Pedagogika, t. 1, PWN, Warszawa 2004.

Nikitorowicz J., Heterogeniczność kultury w indywidualnym dialogu tożsamościowym, [w:] A. Karpińska, M. Zińczuk, P. Remża (red.), Oblicza edukacji w prospektywnym oglądzie, Wydawnictwo Adam Marszałek, Toruń 2019.

Nowocień J., Sport i olimpizm w systemie dydaktyczno-wychowawczym współczesnej szkoły, AWF, Warszawa 2001.

Nowocień J., Studium o pedagogice kultury fizycznej, Akademia Wychowania Fizycznego, Warszawa 2013.

Nowocień J., Pedagogika sportu, Akademia Wychowania Fizycznego, Warszawa 2019.

Retter H., Komunikacja codzienna w pedagogice, tłum. M. Majdak-Piątkowska, wstęp i oprac. B. Śliwerski, GWP, Gdańsk 2005.

Rozporządzenie Ministra Edukacji Narodowej z dnia 27 sierpnia 2012 r. w sprawie podstawy programowej wychowania przedszkolnego oraz kształcenia ogólnego w poszczególnych typach szkół (Dz.U. 2012, poz. 977).

Szymański M.J., Młodzież wobec wartości. Próba diagnozy, IBE, Warszawa 1998.

Śnieżyński M., Dialog edukacyjny, Wydawnictwo Naukowe Papieskiej Akademii Teologicznej, Kraków 2001.

Tarnowski J., Pedagogika dialogu, [w:] B. Śliwerski (red.), Edukacja alternatywna. Dylematy teorii i praktyki, Oficyna Wydawnicza „Impuls”, Kraków 1992.

Tarnowski J., Pedagogika egzystencjalna, [w:] Z. Kwieciński, B. Śliwerski (red.), Pedagogika, t. 1, podręcznik akademicki, PWN, Warszawa 2004.

Tchorzewski A.M. de, Sprawności moralne - nauczyciela wychowania fizycznego, „Wychowanie Fizyczne i Zdrowotne” 2010, nr 2.

Tischner J., Polski kształt dialogu, Wydawnictwo Znak, Kraków 2002.

Wojtyła K., Osoba i czyn oraz inne studia antropologiczne, Towarzystwo Naukowe KUL, Lublin 2000.

Zuchora K., Dialogi olimpijskie. O pięknie i pokoju. Etyce i polityce. Solidarności i edukacji, Fundacja „Centrum Edukacji Olimpijskiej”, Warszawa 2016.

Zuchora K., Nauczyciel i wartości z filozofii kultury fizycznej i pedagogiki sportu, Akademia Wychowania Fizycznego, Warszawa 2009. 
Żukowska Z., Dzieci o sporcie a jego wartości edukacyjne, [w:] E.A. Wesołowska (red.), Człowiek i edukacja. Studia ofiarowane Profesorowi Józefowi Półturzyckiemu z okazji 70-lecia urodzin i 50-lecia pracy naukowej, Wydawnictwo Naukowe Novum, Płock 2004.

Żukowska Z., Fair play w europejskiej kulturze i edukacji, [w:] Z. Żukowska, R. Żukowski (red.), Fair play w europejskiej kulturze i edukacji, Polski Komitet Olimpijski, Klub Fair Play, Warszawa 2004.

Żukowska Z., Żukowski R. (red.), Fair play w europejskiej kulturze i edukacji, Polski Komitet Olimpijski, Klub Fair Play, Warszawa 2004.

Żukowska Z., Żukowski R. (red.), Wychowanie poprzez sport, Ministerstwo Edukacji Narodowej i Sportu, Polskie Towarzystwo Naukowe Kultury Fizycznej, Warszawa 2003. 